\title{
INFLUENCE OF DIFFERENT LEVELS OF GROUND OAK (QUERCUS AEGILOPS) ACORNS ON GROWTH PERFORMANCE AND SOME CARCASS CHARACTERISTICS OF AWASSI LAMBS
}

\author{
Hoger M. Hidayet ${ }^{*}$, Kamal N. Mustafa ${ }^{b}$ \\ ${ }^{a}$ College of Veterinary Medicine, University of Duhok, Duhok, Kurdistan Region, Iraq - (hoger.hidayet@uod.ac) \\ ${ }^{\mathrm{b}}$ College of Agricultural Engineering Sciences, University of Duhok, Duhok, Kurdistan Region, Iraq - (kamal.noman@uod.ac)
}

Received: Mar., 2020 / Accepted: May., 2020 / Published: Jun.,2020

https://doi.org/10.25271/sjuoz.2020.8.2.711

\begin{abstract}
:
This study was aimed to investigate the effect of feeding different levels of oak acorns on growth and some carcass characteristics of Awassi lambs. Twenty lambs were blocked into four groups (5 lambs/group) according to live body weight and fed on one of the experimental diets $(0,5,10$ and $15 \%$ oak acorns). The results showed no effect of dietary treatments on live body weight throughout the period of study, also there were no effects of treatments on carcass traits except for rib-eye muscle area which was largest in the group fed on 5\% acorns. It could be concluded that feeding Awassi lambs on ground oak acorns has no adverse effects on growth performance and health condition.
\end{abstract}

KEYWORDS: Oak Acorns, Sheep, Fattening, Performance, Carcass.

\section{INTRODUCTION}

One of the most important priorities in production is to reduce feeding cost and encourage sheep producers to practice feedlot fattening in order to exploit maximum growth potential of lambs within a limited period of production (Al Jassim et al., 1998). Among the natural resources, trees and shrubs have been used for centuries as important feed resources for livestock and play an important role in the nutrition of livestock in areas where few or no alternatives are available (Papachristou and Nastis, 1996). Oak acorn is a woody plant which is cheap and readily available in many countries.(Mekki et al., 2019; Froutan et al., 2015). Oak leaves and twigs are often grazed by animals including sheep or harvested to be used as livestock fodder during shortage periods (Singh et al., 1996). The main carbohydrate in oak acorns is starch, amounting to over $55 \%$ of the kernel (Saffarzadeh et al., 2000) and may serve as a good and cheap source of energy and minerals (Rababah et al., 2008). Tannins are bioactive phenolic compounds distributed in various plants and act to interfere with protein and lipid metabolism in the rumen, by forming undegradable complexes with feed proteins and affecting the biohydrogenation (Minieri et al., 2014). Tannins are found throughout the oak plant, with higher levels found in the leaves, buds, twigs, while acorns are low in total tannin content (3.2 - 4.4\% DM) and acorn intake by small ruminants could involve positive effects mainly in nitrogen metabolism (Bausch and Carson, 1981; Moujahed et al., 2005). In ruminants, moderate concentrations of tannins in the diet can have beneficial effects (Patra and Saxena, 2011). The low intake of tannins by small ruminants, may lead to positive effects mainly on nitrogen metabolism. Indeed, condensed tannins, at low levels, may complex proteins and protect them from microbial enzymes (Reed et al., 1990) and protect soluble proteins from microbial degradation (Wang et al., 1994; Teferedegne, 2000). Condensed tannins may improve the digestive utilization of feed by ruminants, mainly because of a reduction in protein degradation in rumen and an increase in amino acid flow to the small intestine(Mcnabb et al., 1996). When ewes and cows were fed diets containing less than $4 \%$ tannins of diet dry matter, they exhibited higher retention of nitrogen and lower plasma urea concentrations, as a result of the ability of tannin to preserve feed protein from degradation by rumen microbes (Min et al., 2003; Frutos et al., 2004). Also, in goats Froutan et al. (2014) reported that replacement of ground acorn up to $25 \%$ in the diet did not affect average daily gain, feed conversion ratio and blood parameters of goat kids. Available data linking the effect of acorns on growth and carcass quality of sheep is very limited; therefore, the aim the present study was to evaluate the influence of different levels of oak acorns on performance and carcass traits of Awassi lambs.

\section{MATERIALS AND METHODS}

This experiment was conducted at the Animals project of the College of Agricultural Engineering Sciences, University of Duhok during the period of July first to October first of 2019.

\subsection{Chemical Analysis}

Chemical composition of the oak acorns and other feed ingridients was analysed according to the procedures described by AOAC, (2007). The samples were analysed for their dry matter $\left(105^{\circ} \mathrm{C}\right.$ in oven for $24 \mathrm{~h}$ ), crude protein (Kjeldahl procedure), ash $\left(550^{\circ} \mathrm{C}\right.$ for $6 \mathrm{~h}$ ), ether extract (Soxhlet extractor procedure) was determined by extracting the sample with ether for 6 hours and crude fiber (digesting the sample in diluted acid, diluted base, and then drying and burning at $550 \mathrm{C}^{\circ}$ for 30 minutes. Nitrogen-free extract was calculated by difference. The condensed tannins (CT)

content in the samples of oak acorns was determined according to Makkar et al., (1993). $10 \mathrm{ml}$ of $70 \%$ aqueous acetone was added to $0.2 \mathrm{~g}$ of dried ground sample, and then centrifuged at $3000 \mathrm{~g}$ for 10 minutes at $4^{\circ} \mathrm{C}$. The supernatant was collected and kept on ice. $3 \mathrm{ml}$ of butanol-HCl reagent (butanol-HCI 95:5 v/v) and $0.1 \mathrm{ml}$ of Ferric reagent ( $2 \%$ of ammonium iron sulfate in $2 \mathrm{~N} \mathrm{HCl}$ ) were added to $0.5 \mathrm{ml}$ of supernatant, vortexed, covered

\footnotetext{
* Corresponding author

This is an open access under a CC BY-NC-SA 4.0 license (https://creativecommons.org/licenses/by-nc-sa/4.0/)
} 
with a glass marble and put in heating block at $97^{\circ} \mathrm{C}$ for one hour. After the tubes were cooled, the absorbance was red at $550 \mathrm{~nm}$ via spectrophotometer (Jenway, UK) and condensed tannins were calculated as following:

(A $550 \mathrm{~nm} \times 78.26$ x Dilution factor*) / (\% of DM)

2.1.1. Diet Formulation and Treatments: Oak acorns were collected at Hadena village at Duhok province, Kurdistan region, Iraq. The whole acorns were ground using a hammer mill and spread in shed at $25^{\circ} \mathrm{C}$ for 15 days. Depending on the laboratory analyses, the percentages of raw ingredients were chosen to formulate four experimental diets (Table1); T1 $(0 \%$ oak acorns), T2 (5\% oak acorns), T3 (10\% oak acorns) and T4 (15\% oak acorns). The ingredients were mixed on farm using a mixer machine. The proximate analysis of the experimental diets is shown in Table 1.

2.1.2. Animal Management: Twenty Awassi ewe lambs with an average initial live weight of $21 \pm 0.2 \mathrm{Kg}$ were purchased from a local farm. The ewe lambs were dewormed and vaccinated against enterotoxaemia. The lambs were blocked according to live weight, and then randomly allocated to one of the four treatments, with 5 lambs per treatment. Lambs were housed individually $\left(4 \mathrm{~m}^{2}\right)$. Lambs were offered feed twice a day at 9 a.m. and 5p.m. with free access to fresh water. Feed refusals were recorded twice a week in order to estimate daily feed intake and feed conversion efficiency. Feed samples were collected weekly. To meet lamb growth requirement of feed, the quantity of experimental diets was adjusted weekly according to lamb's live weight to meet AFRC, (1993) requirement. Lambs were weighed weekly until the end of experiment using a portable electronic scale.

2.1.3. Carcass Characteristics: At the end of growth experiment, the animals were slaughtered; eviscerated and hot carcass weight was recorded. The hot carcasses were placed in a refrigerator at $4^{\circ} \mathrm{C}$ for 24 hours. The dressing percentage was calculated next day, and then it was split into two halves between the $12^{\text {th }}$ and $13^{\text {th }}$ rib. The fat thickness over eye-muscle area and muscle's depth were measured by using a Caliper device. The eye-muscle area was determined by tracing the muscle over a transparent paper and measured using a digital planimeter (Planix Tamaya, Japan). The right leg was cut off from the carcass weighed and then the fat, muscle and bone were separated. The percentage of fat, muscle and bone were measured as ratio to total leg weight.

\subsection{Statistical Analysis:}

All the parameters were statistically analyzed using Genstat (Genstat $18^{\text {th }}$ edition, VSN, UK) as a complete randomized At the last week of experiment, there was a numerical increase in mean live body weight $(32.4 \mathrm{Kg})$ of the lambs fed on $\mathrm{T} 4$, which was about $9 \%$ higher than that of lambs fed on control

Table 3. Some Fattening Characteristics of Awassi Lambs Fed

\begin{tabular}{|l|c|c|c|c|c|c|}
\hline \multicolumn{1}{|c|}{ Treatment } & $\mathrm{T} 1$ & $\mathrm{~T} 2$ & $\mathrm{~T} 3$ & $\mathrm{~T} 4$ & \multirow{2}{*}{ SED } & \multirow{2}{*}{ P value } \\
\cline { 1 - 5 } No. of animals & 5 & 5 & 5 & 5 & & \\
\hline Initial body weight & 21.15 & 21.02 & 20.95 & 21.2 & 0.79 & 0.98 \\
\hline *Final body weight & 29.65 & 31.6 & 29.9 & 32.4 & 1.87 & 0.42 \\
\hline Total gain & 8.50 & 10.58 & 8.95 & 11.2 & 1.75 & 0.39 \\
\hline Avg. daily gain & 94.4 & 117.6 & 99.4 & 124.4 & 19.46 & 0.39 \\
\hline DM intake & 120.7 & 124.3 & 122.3 & 122.8 & 1.64 & 0.22 \\
\hline DM intake (kg/d) & 1.34 & 1.38 & 1.35 & 1.36 & 0.01 & 0.22 \\
\hline FCR \% & 11.44 & 11.59 & 12.26 & 8.24 & 1.42 & 0.07 \\
\hline
\end{tabular}

T1: Control, T2: 5\% oak acorns, T3: 10\% oak acorns, T4: 15\% oak acorns, DM: Dry matter, FCR: Feed conversion ratio, P value: Fot treatment.

* Body weights change was analyzed by repeated measures of analysis where $P$ values: treatment $=0.31$, time $=<0.001$, time* treatment $=0.37$. block design with the main effect of diet and to eliminate the effect of block, the animals were chosen from same age and blocked via Genstat software according to their live body weights. The live body weight data were analysed via repeated measure analysis of variance using Genstat (Genstat $18^{\text {th }}$ edition, VSN, UK) as a complete randomized block design with the effects of diet, period and interaction between period and treatment. Week 0 was set as covariate. The analyses were followed by Fisher's least significant difference test. Table1. The composition experimental diets.

\begin{tabular}{|l|l|l|l|l|}
\hline Feedstuffs \% & T1 & T2 & T3 & T4 \\
\hline Barley & 50 & 45 & 40 & 40 \\
\hline Wheat bran & 13 & 12 & 11 & 10 \\
\hline Soybean meal & 15 & 16 & 17 & 18 \\
\hline Corn & 10 & 10 & 10 & 5 \\
\hline Wheat straw & 10 & 10 & 10 & 10 \\
\hline Oak acorns & 0 & 5 & 10 & 15 \\
\hline Vitamins-minerals premix & 1 & 1 & 1 & 1 \\
\hline Iodized Salt & 1 & 1 & 1 & 1 \\
\hline
\end{tabular}

T1: Control, T2: 5\% oak acorns, T3:10\% oak acorns, T4:15\% oak acorns.

Table 2. The proximate analysis of acorn and experimental diets.

\begin{tabular}{|l|l|l|l|l|l|}
\hline Item & $\mathrm{T} 1$ & $\mathrm{~T} 2$ & $\mathrm{~T} 3$ & $\mathrm{~T} 4$ & Acorn \\
\hline $\mathrm{DM} \mathrm{g} / \mathrm{kg}$ & 903 & 909 & 906 & 901 & 593 \\
\hline $\mathrm{OM} \mathrm{g/kg} \mathrm{DM}$ & 965.3 & 958.6 & 957.6 & 938.5 & 968.8 \\
\hline Ash g/kg DM & 34.7 & 41.4 & 42.4 & 61.5 & 31.2 \\
\hline $\mathrm{CP} \mathrm{g} / \mathrm{kg} \mathrm{DM}$ & 131 & 137 & 137 & 147 & 42 \\
\hline $\mathrm{EE} \mathrm{g/kg} \mathrm{DM}$ & 35.7 & 34.5 & 32 & 29.7 & 87.5 \\
\hline $\mathrm{CF}$ g/kg DM & 109 & 104 & 107 & 97.8 & 73.2 \\
\hline $\mathrm{NFE}^{1} \mathrm{~g} / \mathrm{kg} \mathrm{DM}$ & 592.6 & 592.1 & 587.6 & 565 & 359.1 \\
\hline $\begin{array}{l}\mathrm{ME}^{2} \mathrm{MJ} / \mathrm{kg} \\
\mathrm{DM}\end{array}$ & 12.56 & 12.61 & 12.49 & 12.25 & 8.96 \\
\hline $\mathrm{CT} \mathrm{g} / \mathrm{kg} \mathrm{DM}$ & - & - & - & - & 3.76 \\
\hline
\end{tabular}

T1: Control, T2: 5\% oak acorns, T3: 10\% oak acorns, T4: $15 \%$ oak acorns, DM: Dry matter, OM: Organic matter, CP: Crude Protein, EE: Ether extract, CF: Crude fiber, NFE: Nitrogen-free extract, ME: Metabolizable energy, CT: Condensed tannins.

${ }^{1} \mathrm{NFE} \%=1000-($ Water $+\mathrm{Ash}+\mathrm{EE}+\mathrm{CP}+\mathrm{CF}$ contents $)$.

${ }^{2} \mathrm{ME}$ was calculated according to (MAFF, 1975),ME= $\left(\mathrm{CP} * 0.02+\mathrm{EE}^{*} 0.031+\mathrm{Cf}^{*} 0.005+\mathrm{NFE} * 0.014\right)$.

diet $(29.65 \mathrm{Kg})$, but this increase in live weight was statistically insignificant. 


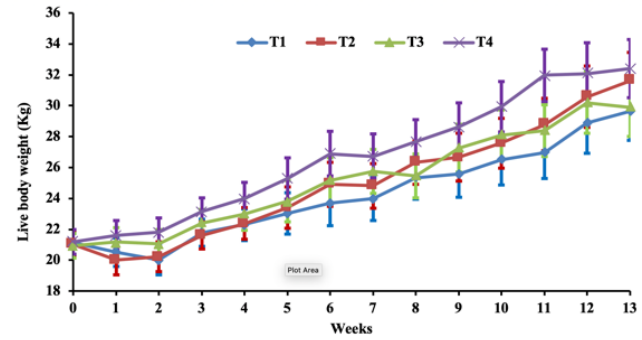

Figure 1. Effect of dietary levels of oak acorns on growth rate of lambs. SED values: Treatment $=1.22$, time $=0.35$, time $*$ treatment $=$ 1.40. $\mathrm{P}$ values: Treatment $=0.31$, time $=<0.001$, time $*$ treatment $=0.37$

The results are in accordance with those reported by Mekki et al. (2019) that live weight gain was not affected in Barberine lambs fed pasture and oak acorns as compared to lambs fed on pasture and barley. The results are comparable to that of $\mathrm{Al}$ Jassim et al. (1998) as they demonstrated no effect of feeding Awassi lambs on diets containing $25 \%$ oak acorns on live weight gain. In the current study the absence of the effect of feeding oak acorns may be attributed to the non-significant effects of acorns on feed intake and/or due to the similar nutritive value of dietary treatments.

2.2.1 Dry Matter Intake: There was no effect of dietary levels of oak acorns on DM intake. Al Jassim et al. (1998) also found that feeding Awassi lambs on a diet containing 25\% oak acorns did not cause significant difference in feed conversion ratio. The use of conservative dose of tannins may explain the absence of an adverse effect of tannins on animal performance (Krueger et al., 2010). It has been shown that many mammals, especially browsers, have the ability to produce proline-rich salivary proteins, these proteins are able to bind to dietary tannins to inactivate them (Austin et al., 1989). The binding of proline-rich salivary proteins and tannins are responsible for astringent taste (Prinz and Lucas, 2008) . Proline-rich proteins are not produced by the salivary glands of sheep (Makkar, 2003) . Therefore, the absence of significant difference in DM intake due to astringent taste mechanism associated with tannins may not occur in sheep. In addition, the absence of dietary effects of oak acorns on DM intake may be justified also by the findings of Ben Salem et al. (2005) who demonstrated that in lambs, there is a clear adaptation period (from 24 to 72 days) to tanniniferous feeds.

There was a trend $(\mathrm{P}=0.07)$ in feed conversion ratio of lambs fed on T4 $(8.24 \mathrm{Kg} \mathrm{DM} / \mathrm{Kg} \mathrm{LBW})$ which was lower than the means of other groups. Although the lambs fed T4 exhibited the highest daily weight gain that was $24 \%$ higher than that of control, but this increase was numerical.

2.2.2. Carcass Traits: The effect of dietary treatments on carcass traits is shown in table 4.

Table 4 Some Carcass Traits of Awassi Lambs Fed Different Levels of Oak Acorns.

\begin{tabular}{|c|c|c|c|c|c|c|}
\hline Treatment & $\mathrm{T} 1$ & $\mathrm{~T} 2$ & $\mathrm{~T} 3$ & $\mathrm{~T} 4$ & \multirow{2}{*}{ SED } & \multirow{2}{*}{ P value } \\
\hline No. of animals & 5 & 5 & 5 & 5 & & \\
\hline Slaughter weight kg & 29.65 & 31.6 & 29.9 & 32.4 & 1.87 & 0.42 \\
\hline Carcass weight kg & 14.06 & 14.81 & 14.89 & 14.85 & 0.92 & 0.62 \\
\hline Chilled carcass weight kg & 13.75 & 14.46 & 14.46 & 14.46 & 0.85 & 0.57 \\
\hline Shrinkage \% & 2.25 & 2.37 & 3.01 & 2.60 & 0.85 & 0.82 \\
\hline Dressing \% & 47.35 & 46.96 & 46.4 & 45.99 & 1.56 & 0.83 \\
\hline Rib-eye area mm m $^{2}$ & $10.2^{\mathrm{a}}$ & $12.75^{\mathrm{b}}$ & $9.75^{\mathrm{a}}$ & $8.99^{\mathrm{a}}$ & 0.81 & 0.004 \\
\hline Rib-eye depth mm & 26.5 & 28.07 & 27.26 & 24.32 & 2.12 & 0.36 \\
\hline Back fat thickness mm & 1.89 & 1.91 & 2.44 & 2.18 & 0.41 & 0.52 \\
\hline Leg weight kg & 2.3 & 2.14 & 2.08 & 2.13 & 0.12 & 0.36 \\
\hline Lean \% & 59.29 & 66.87 & 57.44 & 60.3 & 3.25 & 0.06 \\
\hline Fat \% & 19.45 & 14.93 & 15.25 & 16.39 & 1.71 & 0.08 \\
\hline Bone \% & $18.52 \mathrm{a}$ & $17.53 \mathrm{a}$ & $22.73 \mathrm{~b}$ & $21.01 \mathrm{ab}$ & 1.55 & 0.02 \\
\hline
\end{tabular}

Different letters within the same row refers to significant difference, T1: Control, T2: 5\% oak acorns, T3: 10\% oak acorns, T4: $15 \%$ oak acorns, $P$ value: For treatment.

The largest rib eye muscle area $\left(12.75 \mathrm{Cm}^{2}\right)$ was found in the carcasses of lambs fed on T2 which was significantly $(\mathrm{P}=0.004)$ higher than that of the other groups. The acorns used in this experiment contained $3.76 \mathrm{~g}$ condensed tannins $/ \mathrm{kg}$ feed $\mathrm{DM}$, thus the lambs fed on $\mathrm{T} 2$ received $0.188 \mathrm{~g}$ condensed tannin/ $\mathrm{kg}$ feed DM. The largest rib eye muscle area from lambs fed this treatment might be due to the fact that low levels of tannins in the diet affect the rumen fermentation through decreasing feed protein degradability by making complexes with feed proteins leading to higher non ammonia nitrogen supply to the intestine (Makkar, 2003) and increasing the absorption of amino acids in the intestine (Waghorn and Shelton, 1997). In addition to this, it is evident that low levels of tannins cause to increase the efficiency of microbial protein synthesis in the rumen (Makkar et al., 1998). These two mechanisms are beneficial toward better production in ruminants including meat. Furthermore, high concentration of tannins in the diet cause to decrease nutrient digestibility (Makkar et al., 1995). More studies are needed to determine the optimum level of tannins in the diet as related to positive effects.

The lambs fed on T3 and T4 showed a numerically higher back fat thickness as compared to that of control. This increase in back fat thickness may be explained by the suggestion of Barry et al, (1986) that there is a positive correlation between dietary condensed tannins level and growth hormone which may increase the lipid turnover.
2.2.3. Physical Dissection: The highest mean of muscle percentage in the right leg was found in the carcasses of lambs fed on T2 which was $66.87 \%$ of the leg and this tended to be higher $(\mathrm{P}=0.06)$ than that of lambs the other groups. The mean percentage of fat in right leg of the carcasses of lambs fed on control diet was $19.45 \%$ and this tended to be the highest $(\mathrm{P}=0.08)$ as compared to that of other groups. Lambs Fed on T3 showed a significant $(\mathrm{P}=0.02)$ increase in right leg bone percentage $(22.73 \%)$ as compared to that of control $(18.52 \%)$ and that of lambs fed on T2 (17.53\%).

\section{CONCLUSIONS}

It could be concluded that inclusion of oak acorns up to $15 \%$ in the diets of Awassi lambs has no adverse effects on animal performance and carcass characteristics, also no health problems were reported. Further research is needed to study the effect of oaks on meat quality parameters.

\section{REFERENCES}

AFRC 1993. Energy and Protein Requirements of Ruminants: An Advisory Manual Prepared by the AFRC Technical Committee on Responses to Nutrients. CAB International, Wallingford, Oxon, UK.

AOAC 2007. Official Methods of Analysis. Association of Official Analytical Chemists, Arlington, VA.

Austin PJ, Suchar LA, Robbins CT and Hagerman AE 1989. Tannin- 
binding proteins in saliva of deer and their absence in saliva of sheep and cattle. Journal of Chemical Ecology 15, 13351347.

Barry T, Allsop T and Redekopp C 1986. The role of condensed tannins in the nutritional value of Lotus pedunculatus for sheep. British Journal of Nutrition 56, 607-614.

Bausch JD and Carson TL 1981. Oak poisoning in cattle oak poisoning in cattle. Iowa State University Veterinarian 43, 108-111.

Froutan E, Azizi O, Sadeghi G, Fatehi F and Lashkari S 2015. Effects of different concentrations of ground oak acorn on growth performance, blood parameters and carcass characteristics of goat kids. Animal Production Science 55, 87-92.

Frutos P, Hervás G, Giráldez FJ and Mantecón AR 2004. Review. Tannins and ruminant nutrition. Spanish Journal of Agricultural Research 2, 191-202.

Al Jassim R, Ereifej K, Shibli R and Abudabos A 1998. Utilization of concentrate diets containing acorns ( Quercus aegilops and Quercus coccifera ) and urea by growing Awassi lambs. Small Ruminant Research 29, 289-293.

Krueger WK, Gutierrez-Bañuelos H, Carstens GE, Min BR, Pinchak WE, Gomez RR, Anderson RC, Krueger NA and Forbes TDA 2010. Effects of dietary tannin source on performance, feed efficiency, ruminal fermentation, and carcass and non-carcass traits in steers fed a high-grain diet. Animal Feed Science and Technology 159, 1-9.

MAFF 1975. Energy allowances and feeding systems for ruminants. Technical Bulletin.

Makkar HPS 2003. Effects and fate of tannins in ruminant animals, adaptation to tannins, and strategies to overcome detrimental effects of feeding tannin-rich feeds. Small Ruminant Research 49, 241-256.

Makkar HPS, Blummel M and Becker K 1995. In vitro effects of and interactions between tannins and saponins and fate of tannins in the rumen. Journal of the Science of Food and Agriculture 69, 481-493.

Makkar HPS, Blümmel M and Becker K 1998. Application of an in vitro gas method to understand the effects of natural plant products on availability and partitioning of nutrients. British Society of Animal Science 22, 147-150.

Makkar HPS, Blummel M, Borowy NK and Becker K 1993. Gravimetric determination of tannins and their correlations with chemical and protein precipitation methods. Journal of the Science of Food and Agriculture 61, 161-165.

Mcnabb WC, Waghorn GC, Peters JS and Barry TN 1996. The effect of condensed tannins in Lotus pedunculatus on the carboxylase (EC 4.1 . 1 .39; Rubisco) protein in the rumen and solubilization and degradation of ribulose-1,5-bisphosphate the sites of Rubisco digestion. British JournaI of Nutrition 76 , 535-549.

Mekki I, Smeti S, Hajji H, Yagoubi Y, Mahouachi M and Atti N 2019. Effect of oak acorn (Quercus ilex) intake during suckling and fattening of Barbarine lambs on growth, meat quality and fatty acid profile. Journal of Animal and Feed Sciences 28, 22-30.
Min BR, Barry TN, Attwood GT and McNabb WC 2003. The effect of condensed tannins on the nutrition and health of ruminants fed fresh temperate forages: A review. Animal Feed Science and Technology 106, 3-19.

Minieri S, Buccioni A, Rapaccini S, Pezzati A, Benvenuti D, Serra A and Mele M 2014. Effect of Quebracho tannin extract on soybean and linseed oil biohydrogenation by solid associated bacteria: An in vitro study. Italian Journal of Animal Science $13,604-608$

Moujahed N, Ben Mustapha C and Kayouli C 2005. Effect of maturity stage on chemical composition, in sacco degradation and in vitro fermentation of acorns (Quercus coccifera L .). Options Méditerranéennes 67, 413-417.

Papachristou TG and Nastis AS 1996. Influence of deciduous broadleaved woody species in goat nutrition during the dry season in northern Greece. Small Ruminant Research 20, 15 22.

Patra AK and Saxena J 2011. Exploitation of dietary tannins to improve rumen metabolism and ruminant nutrition. Journal of the Science of Food and Agriculture 91, 24-37.

Prinz JF and Lucas PW 2008. Saliva tannin interactions. Journal of Oral Rehabilitation 27, 991-994.

Rababah TM, Ereifej KI, Al-mahasneh MA and Alhamad MN 2008. The physicochemical composition of acorns for two mediterranean Quercus species. 4, 131-137.

Reed JD, Soller H and Woodward A 1990. Fodder tree and straw diets for sheep: intake, growth, digestibility and the effects of phenolics on nitrogen utilisation. Animal Feed Science and Technology 30, 39-50.

Saffarzadeh A, Vincze L and Csabo J 2000. Determination of some anti-nutritional factors and metabolizable energy in Quercus branti, Pistacia atlantica and Pistacia khinjuk seeds as new poultry diets. Acta Agraria Kaposváriensis 4, 41-47.

Ben Salem H, Nefzaoui A, Makkar HPS, Hochlef H, Ben Salem I and Ben Salem L 2005. Effect of early experience and adaptation period on voluntary intake, digestion, and growth in Barbarine lambs given tannin-containing (Acacia cyanophylla Lindl. foliage) or tannin-free (oaten hay) diets. Animal Feed Science and Technology 122, 59-77.

Singh P, Biswas JC, Somvanshi R, Verma AK, Deb SM and Dey RA 1996. Performance of pashmina (Cheghu) goats fed on oak ( Quercus semecarpifolia) leaves. Small Ruminant Research 22, 123-130.

Teferedegne B 2000. New perspectives on the use of tropical plants to improve ruminant nutrition. Proceedings of the Nutrition Society 59, 209-214.

Waghorn GC and Shelton ID 1997. Effect of condensed tannins in Lotus corniculatus on the nutritive value of pasture for sheep. Journal of Agricultural Science 128, 365-372.

Wang Y, Waghorn GC, Barry TN and Shelton ID 1994. The effect of condensed tannins in Lotus corniculatus on plasma metabolism of methionine, cystine and inorganic sulphate by sheep. British Journal of Nutrition 72, 923-935. 